\title{
A new Gravesia (Melastomataceae, Sonerileae) from the Bemangidy-Ivohibe rainforest of southeastern Madagascar
}

\author{
Frank Almeda \& Heritiana Ranarivelo
}

\begin{abstract}
ALMEDA, F. \& H. RANARIVELO (2018). A new Gravesia (Melastomataceae, Sonerileae) from the Bemangidy-Ivohibe rainforest of southeastern Madagascar. Candollea 73: 1-5. In English, English and French abstracts. DOI: http://dx.doi.org/10.15553/c2018v731a1

Gravesia parvula Almeda \& Ranarivelo (Melastomataceae, Sonerileae), a new species from the Bemangidy-Ivohibe forest of southeastern Madagascar, is described, illustrated, mapped, and compared with superficially similar Malagasy species. In addition to its dwarf rosette-like habit, it is distinguished by the semi-succulent obovate to oblanceolate 1-nerved leaf blades with entire distally repand margins, indumentum of minute dark brown gland-like trichomes that are rounded to shallowly bilobed at the apex, stamens with external (antesepalous) and internal (antepetalous) whorls somewhat unequal in size in each flower, obovoid to oblong anther thecae with cleft-like ventrally inclined apical pores, and capitate stigma. A conservation assessment of "Endangered" is recommended for this species based on IUCN Red List Categories and Criteria.

\section{Résumé}

ALMEDA, F. \& H. RANARIVELO (2018). Un Gravesia nouveau (Melastomataceae, Sonerileae) de la forêt humide de Bemangidy-Ivohibe au sud-est de Madagascar. Candollea 73: 1-5. En anglais, résumés anglais et français. DOI: http://dx.doi.org/10.15553/c2018v731a1

Gravesia parvula Almeda \& Ranarivelo (Melastomataceae, Sonerileae), une nouvelle espèce originaire de la forêt de Bemangidy-Ivohibe, au sud-est de Madagascar, est décrite, illustrée et cartographiée. Elle est comparée à d'autres espèces malgaches qui lui sont similaires. En plus de son aspect nain et en rosette, elle se distingue par ses feuilles semi-succulentes à une seule nervure, de forme ovale à oblanceolée, et dont les bords sont légèrement ondulés. Par ailleurs, son indument est composé de minuscules trichomes glandulaires sombres dont les apex sont ronds ou légèrement bilobés. Les étamines de chaque fleur sont de taille alternativement inégale d'une fleur à l'autre. Les anthères sont ovoïdes ou oblongues avec des pores apicaux inclinés et fendus ventralement. Les stigmas sont en capitule. Le status de conservation «En danger» est recommendé pour cette l'espèce en se basant sur les Catégories et les Critères de la Liste Rouge de l'UICN.
\end{abstract}

\section{Keywords}

MELASTOMATACEAE - Gravesia - Madagascar - New species - Taxonomy - Conservation

Address of the authors:

California Academy of Sciences, Institute for Biodiversity Science \& Sustainability, Department of Botany, 55 Music Concourse Drive, Golden Gate Park, San Francisco, CA 94118-4599, USA. E-mail: falmeda@calacademy.org 


\section{Introduction}

Gravesia Naudin is unique among genera of the paleotropical Melastomataceae tribe Sonerileae in having a major center of diversity in Madagascar (PERrier De LA Bâthie, 1951; Madagascar Catalogue, 2018). Of the 113 described species, 108 are endemic to Madagascar. The other five species of Gravesia are restricted to tropical regions of the African continent with three species in Tanzania (Wickens, 1975), one in the Democratic Republic of Congo (JacQues-FÉLIX, 1974), and one in Gabon (JacQues-FÉLIX, 1983). In terms of diversity in growth habit, Gravesia has few equals among Melastomataceae on land masses of comparable size anywhere else in the tropics and stands out as one of the world's most spectacular examples of evolutionary radiation on an island (Almeda, 2003).

The remarkable dwarf species of Gravesia described here was collected in the course of recent botanical inventories in southeastern Madagascar's Tsitongambarika Forest Complex, of which the Bemangidy-Ivohibe rainforest is a part. These inventories have been carried out by the Missouri Botanical Garden in collaboration with Rio Tinto QMM and BirdLife International in connection with the Rio Tinto QMM biodiversity offset conservation project (RE:Common \& WRM, 2016). In addition, the Swedish Museum of Natural History has conducted recent botanical inventory activity in the Bemangidy-Ivohibe forest. Other new species of Melastomataceae that have been collected in the course of these inventory projects will be described in forthcoming publications.

\section{Taxonomic treatment}

Gravesia parvula Almeda \& Ranarivelo, spec. nova (Fig. 1, 2).

Holotypus: Madagascar. Reg. Anosy: Fort Dauphin Distr., Iabakoko Comm., Bemangidy-Ivohibe forest,

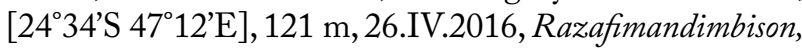
Razafindrahaja \& Atalaby 1517 (CAS!; iso-: S, TAN).

Unusual and unique among Gravesia Naudin of Madagascar and Africa in having a dwarf rosette-like habit, semi-succulent obovate to oblanceolate 1-nerved leaf blades with entire margins that are distally repand, indumentum of minute (up to $0.1 \mathrm{~mm}$ long) gland-like trichomes that are rounded to shallowly bilobed at the apex and constricted into an inconspicuous translucent stipe-like base, laterally compressed calyx teeth, stamens with external (antesepalous) and internal (antepetalous) whorls somewhat unequal in size in each flower, small oblong to obovoid anther thecae with cleft-like ventrally inclined apical pores, and capitate stigmas.

Delicate rosette-like radicant perennial herbs $2-6 \mathrm{~cm}$ tall, mostly unbranched from the base. Cauline internodes \pm rounded to bluntly quadrate, densely covered with dark brown (sepia-colored) minute (up to $0.1 \mathrm{~mm}$ long) gland-like trichomes that are variously compressed or tumescent with a rounded to shallowly bilobed apex and constricted into an inconspicuous translucent stipe-like base. Nodes \pm compressed or somewhat swollen at the base of each petiole and covered with an indumentum like that of the internodes. Leaves opposite and decussate, isomorphic in size and shape in each pair. Leaves semi-succulent when fresh becoming chartaceous when dry; petioles 2-7 mm long, copiously covered with indumentum like the internodes; blades olive green adaxially, paler green to yellowish-green abaxially when dry, widely spreading, 0.6-2.5 $\times 0.4-1.2 \mathrm{~cm}$, obovate to \pm oblanceolate, 1 -nerved but only vaguely evident on the abaxial surface, apex rounded, base attenuate to rarely obtuse, moderately to sparingly and irregularly covered on both surfaces with the gland-like trichomes of the internodes and petioles, the margins entire but commonly repand for at least the distal half of the blade, often hyaline and sometimes revolute to varying degrees when dry. Inflorescence a terminal umbelliform cyme of three to four flowers but commonly reduced to paired or single flowers on an erect solitary peduncle $1.3-2.7 \mathrm{~cm}$ long; pedicel $2.5-5 \mathrm{~mm}$ long, the inconspicuous subtending bracteoles $0.5 \mathrm{~mm}$ long and mostly less than $0.25 \mathrm{~mm}$ wide, narrowly and bluntly oblong-lanceolate. Flowers 5-merous and diplostemonous; hypanthium (at anthesis) $2 \times 2 \mathrm{~mm}$, infundibuliform, moderately to copiously covered with the gland-like indumentum like the internodes and peduncles; calyx tube $0.5-1 \mathrm{~mm}$ long, calyx lobes $0.5 \mathrm{~mm}$ long and $1-1.5 \mathrm{~mm}$ wide at the base, broadly deltoid, antrorsely to widely spreading, sparsely beset with indumentum like that of the hypanthium abaxially but essentially glabrous adaxially, the exterior calyx teeth (terminal extensions of the hypanthial vascular ribs) laterally compressed and projecting about $0.25 \mathrm{~mm}$ beyond the calyx lobes. Petals $4.5-5 \times 2-2.5 \mathrm{~mm}$, narrowly obelliptic to narrowly obovate, obliquely apiculate at the apex, pink but darker pinkish-red at the base, entire and eciliate. Stamens 10, dimorphic in size and forming a ring around the style at anthesis. Large (antesepalous) stamens 5; filaments 2.5-3mm long, pink; thecae $0.75 \times 0.75 \mathrm{~mm}$, white to pale yellowish when dry, oblong to obovoid, the apical pore \pm ventrally inclined and cleft-like; connective somewhat thickened dorsally and prolonged dorso-basally into a deflexed acute or oblong appendage $0.2 \mathrm{~mm}$ long. Small (antepetalous) stamens 5; filaments 2-2.5 mm long; thecae $0.5 \times 0.2 \mathrm{~mm}$, white to pale yellowish when dry, narrowly oblong to obovoid, the apical pore ventrally inclined and cleft-like; connective thickened dorsally and prolonged dorso-basally into a deflexed acute or oblong appendage $0.1 \mathrm{~mm}$ long. Ovary globose, glabrous, apex flat or low-domed and bright red when fresh, $4 / 5$ inferior, 5 -locular; style $4 \times 0.1 \mathrm{~mm}$, terete and straight, glabrous and terminating in a capitate stigma that protrudes just beyond the clustered anthers. Capsule globose, $2.5 \times 4 \mathrm{~mm}$, loculicidal, enveloped by the hypanthium and persistent calyx lobes. Seeds ovoid-clavate 


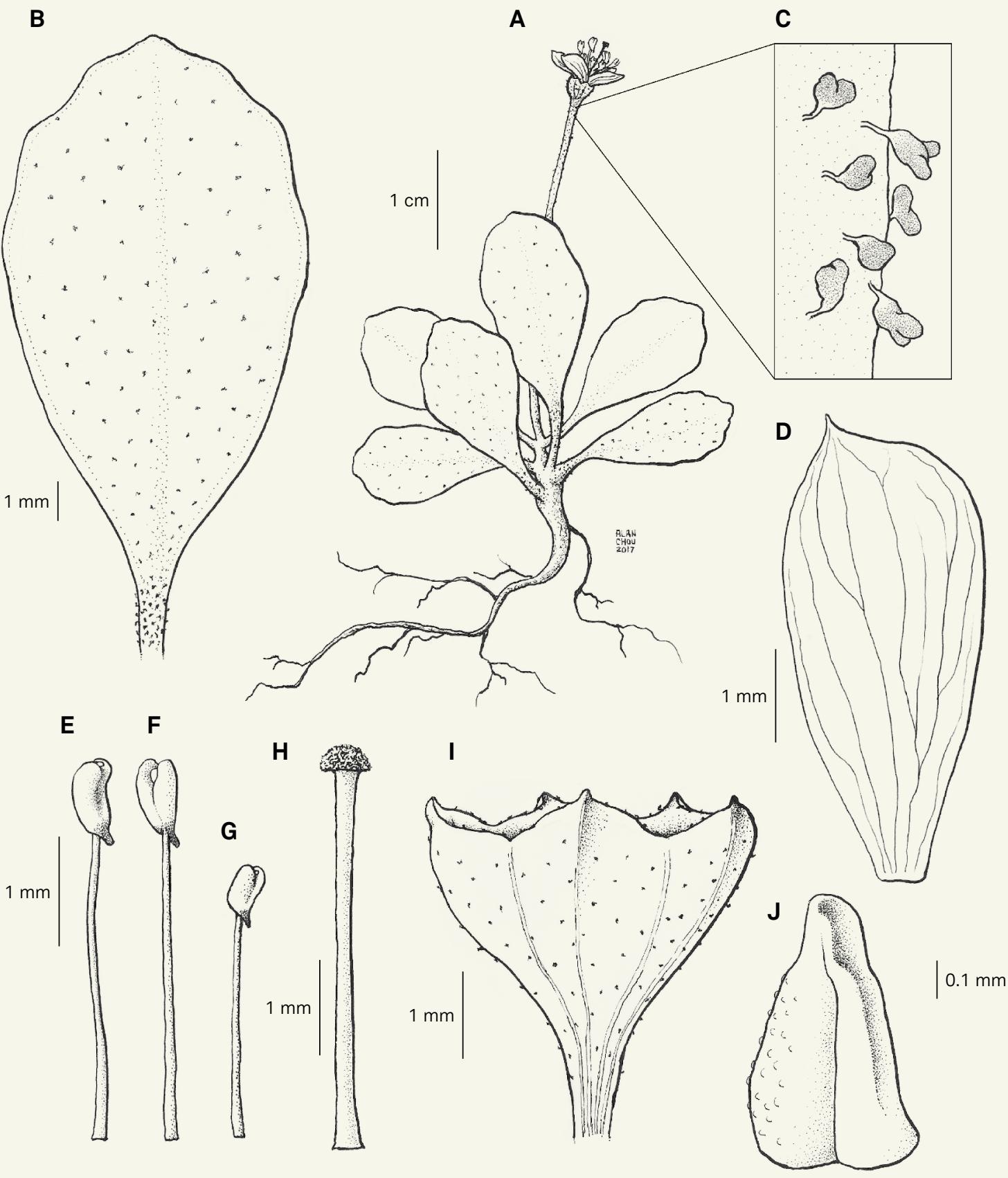

Fig. 1. - Gravesia parvula Almeda \& Ranarivelo. A. Habit; B. Representative leaf (abaxial surface); C. Detail of indumentum on inflorescence peduncle; D. Petal (adaxial surface); E. Antesepalous (large) stamen (partial dorsal view); F. Antesepalous (large) stamen (ventral view);

G. Antepetalous (small) stamen (dorsal view); H. Style and stigma; I. Mature hypanthium enveloping capsule (profile view); J. Seed.

[A-C, E-F, H-J: Razafimandimbison et al. 1517, CAS; D, G: Razakamalala et al. 2327, MO] [Drawings: A. Chou] 


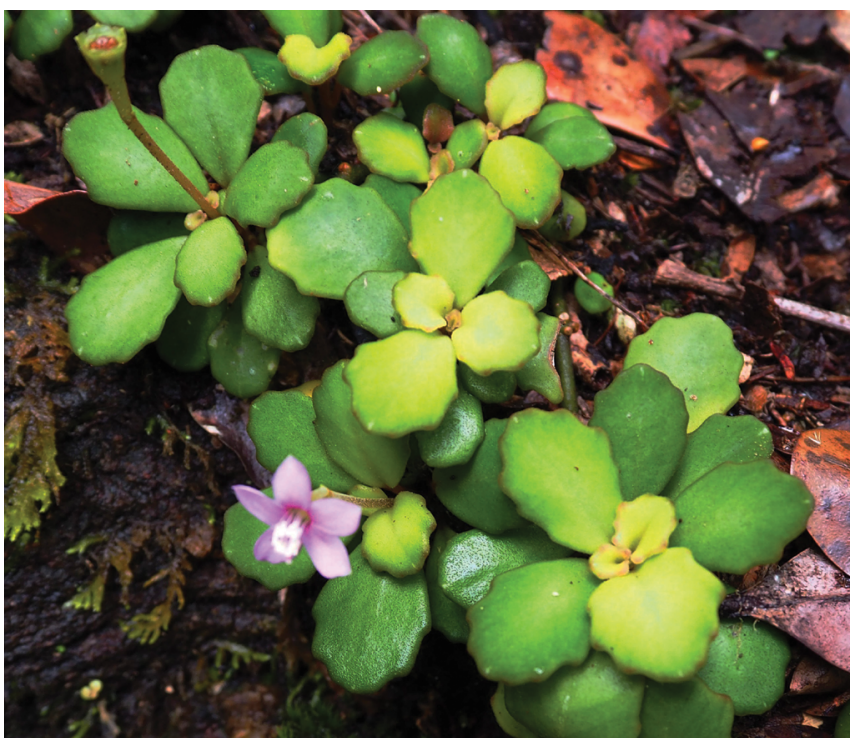

Fig. 2. - Gravesia parvula Almeda \& Ranarivelo showing habit, a flower (lower left), and an infructescence reduced to a single capsule with enveloping hypanthium (upper left).

[Photo: S. Razafimandimbison]

to ovoid-cuneiform, beige to pale brown, $0.75 \mathrm{~mm}$ long and $0.5 \mathrm{~mm}$ wide at the chalazal end; lateral and antiraphal symmetrical planes narrowly ovate, the highest point toward the chalazal side. Raphal zone ovate to elliptic-ovate, ca. $25 \%$ of the length of the seed with a well-defined \pm triangular vesicular swelling (bladder-like appendage) extending from the base of the raphe to the wider chalazal end, testa somewhat angulaterounded, irregularly and inconspicuously papillate.

Etymology. - The specific epithet, which is derived from the Latin word parvus, emphasizes the diminutive habit and size of its vegetative and reproductive organs.

Distribution and habitat. - Gravesia parvula is known only from the Bemangidy-Ivohibe forest in southeastern Madagascar on the eastern side of the Vohimena massif that runs north of Fort Dauphin where it reportedly grows on rocks in dense evergreen rainforest at 112-395 m elevation (Fig. 3).

Phenology. - Flowering and fruiting collections have been made in November, January, and April.

Conservation status. - Gravesia parvula appears to be restricted to the Bemangidy-Ivohibe forest. This forest, which comprises about 25,000 hectares, is one of three protected sites comprising the Tsitongambarika forest complex (TGK) established by the Rio Tinto QMM biodiversity offset project in the Anosy region of southeastern Madagascar. These offset sites are intended to compensate for the loss of biodiversity that has resulted from the destruction of the coastal forest at Rio Tinto QMM's ilmenite mining site at Fort Dauphin which is also in the Anosy region. The TGK forest complex, with about 65,000 hectares and more than $80 \%$ species endemism, is the largest expanse of lowland humid forest in southeastern Madagascar (Olsen et al., 2011). With georeferenced data from cited collections, we used GeoCAT (Bachman \& MoAT, 2012) to calculate extent of occurrence (EOO) and area of occupancy (AOO) based on a user-defined cell of $4 \mathrm{~km}^{2}$. The EOO for G. parvula is $<0.5 \mathrm{~km}^{2}$ and the $\mathrm{AOO}$ is $12 \mathrm{~km}^{2}$. We assign this species a preliminary status of "Endangered" [EN B2ab(iii)] following IUCN Red List Categories and Criteria (IUCN, 2012) in view of its limited geographic distribution, small known population, and apparent restriction to rocky substrates. Although the forest in which this new species grows is currently protected, there are long-term challenges and concerns because this particular offset does not address the negative social impacts it is causing for nearby villages such as Antsotso where local villagers lost the land used to grow their manioc food crop at the edge of the protected forest. Every effort to protect the biodiversity of forests in Madagascar is to be applauded but biodiversity conservation can be most effective and long-lasting when alternative sources of income and forest products are made available to local communities affected by conservation offset projects (Olsen et al., 2011).

Notes. - Gravesia parvula is readily assigned to Gravesia sect. Primuloideae H. Perrier (G. primuloides Cogn., type species) based on its herbaceous, rosette-like subacaulescent habit, umbelliform few-flowered inflorescence borne on an elongate peduncle, partially inferior ovary, unconstricted hypanthial apex below the torus, and anthers that are appendaged dorso-basally (Perrier de LA BÂthie, 1932,1951). This new species does not key satisfactorily to any of the 44 species in sect. Primuloideae (Perrier de la Bâthie, 1951) nor does it appear to have any close relatives among described species in Madagascar or continental Africa. Among species assigned to the subgenus Gravesia and section, only G. biauriculata $\mathrm{H}$. Perrier is superficially similar in being a dwarf species but it has a consistently acaulescent rosette habit and differs by its ovate 5-7-nerved leaf blades that are cordate at the base, petioles 5-30 mm long with copious spreading or deflexed purplish trichomes, prevailingly 4-merous flowers, white petals, and anther connectives that are thickened and prolonged dorso-basally into a subacute appendage with two small lateral hooks (PERrier de LA BÂThIE, 1951: 85).

The stamens of Gravesia are typically isomorphic in size and shape but at least one other species, G. lamiana $\mathrm{H}$. Perrier (also of sect. Primuloideae), has stamens with external (antesepalous) and internal (antepetalous) whorls somewhat unequal in size in each flower like G. parvula (PERRIER DE LA BÂTHIE, 1951: 105). In G. lamiana the much larger ovate 


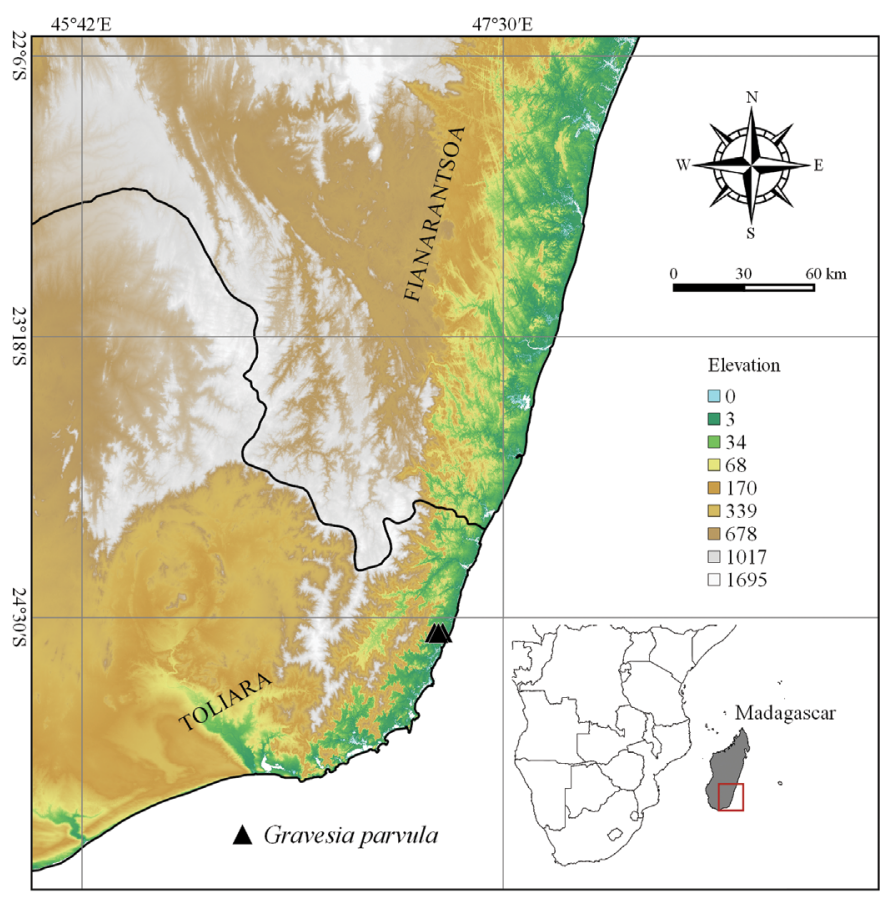

Fig. 3. - Map showing the distribution of Gravesia parvula Almeda \& Ranarivelo.

leaves $(8.5-17 \times 4-9.5 \mathrm{~cm})$ are bullate adaxially, 7-9-nerved, and the anther connectives are unappendaged.

This species exhibits some striking morphological convergence with other members of the family. In habit, G. parvula is superficially similar to some of the dwarf acaulescent herbaceous species of the neotropical genus Macrocentrum J.D. Hooker of the tribe Merianieae (Penneys et al., 2010). In Macrocentrum the flowers are solitary at the ends of leafy branchlets or secund in terminal few-flowered cymes, the anthers are isomorphic, linear-subulate with a pedoconnective prolonged below the anther thecae and a connective prolonged dorso-basally into an acute toothlike appendage, and the ovary is usually 3-locular (rarely 2- or 4-locular) and free from the hypanthium. Several dwarf species of Macrocentrum commonly grow on rocks or tree trunks, so this dwarf acaulescent or subacaulescent radicant habit may be an adaptation to life on these kinds of substrates.

Paratypi. - Madagascar. Prov. Toliara: Anosy Reg., Fort Dauphin, Iaboko, Antsotso, 2433'52”S 47 14'25”E, 112 m, 26.XI.2005, Razakamalala et al. 2327 (MO, P, TAN); ibid. loco, 24³3’51”S 47'12’20”E, 395 m, 28.I.2015, Razanatsima et al. 1387 (MO, TAN).

\section{Acknowledgements}

We thank Alan Chou for the line drawing, Ricardo B. Pacifico for the distribution map, the Naturhistoriska Riksmuseet, Stockholm (S) for a gift of specimens, Sylvain Razafimandimbison for the image of $G$. parvula taken in the field, the Missouri Botanical Garden (MO) for a loan, and Armand Randrianasolo and Heidi Schmidt for information on collections of Melastomataceae from the Bemangidy-Ivohibe forest.

\section{References}

Almeda, F. (2003). Melastomataceae: Princess Flowers. In: Goodman, S.M. \& J.P. Benstead (ed.), The Natural History of Madagascar: 375-379. University of Chicago Press, Chicago.

Bachman, S. \& J. Moat (2012). GeoCAT - an open source tool for rapid Red List assessments. Bot. Gard. Conservation Int. J. 9 [http://geocat.kew.org].

IUCN (2012). IUCN Red List Categories and Criteria: Version 3.1. Ed. 2. IUCN Species Survival Commission, Gland \& Cambridge.

JACQUes-FÉlix, H. (1974). Melastomataceae nouvelles ou peu connues du Zaire. Bull. Jard. Bot. Natl. Belg. 44: 161-171.

Jacques-FÉlix, H. (1983). Mélastomatacées. In: Leroy, J.-F. (ed.), Fl. Gabon 25.

Madagascar Catalogue (2018). Catalogue of the plants of Madagascar. Missouri Botanical Garden, St. Louis \& Antananarivo [http://www.tropicos.org/project/mada].

Olsen, N., J. Bishop \& S. Anstee (2011). Exploring ecosystem valuation to move towards net positive impact on biodiversity in the mining sector. IUCN and Rio Tinto Technical Series 1 [https://portals. iucn.org/library/efiles/documents/2011-062.pdf].

Penneys, D.S., F. Almeda \& F.A. Michelangeli (2010). Progress towards a comprehensive phylogenetic analysis and revised classification of the Melastomataceae. Scientific Abstracts no. 509. Botany 2010, July 31-August 4. Providence, Rhode Island.

Perrier de la BÂthie, H. (1932). Les Mélastomatacées de Madagascar. Mém. Acad. Malgache 12.

Perrier de la BÂthie, H. (1951). Mélastomatacées. In: Humbert, H. (ed.), Fl. Madagascar Comores 153.

Re:Common \&WRM (2016). Rio Tinto's biodiversity offset in Madagascar: Double landgrab in the name of biodiversity? [http://www. wrm.org.uy/wp-content/uploads/2016/04/RioTintoBiodivOffsetMadagascar_report_EN_web.pdf].

Wickens, G.E. (1975). Melastomataceae. In: Polhill, R.M. (ed.), Fl. Trop. E. Africa. 